\title{
Foraging range and habitat use by Cape Vulture Gyps coprotheres from the Msikaba colony, Eastern Cape province, South Africa
}

\begin{tabular}{|c|c|}
\hline \multicolumn{2}{|c|}{$\begin{array}{l}\text { Authors: } \\
\text { Morgan B. Pfeiffer } \\
\text { Jan A. Venter } \\
\text { Colleen T. Downs }\end{array}$} \\
\hline \multicolumn{2}{|c|}{$\begin{array}{l}\text { Affiliations: } \\
{ }^{1} \text { School of Life Sciences, } \\
\text { University of KwaZulu-Natal, } \\
\text { South Africa }\end{array}$} \\
\hline \multicolumn{2}{|c|}{$\begin{array}{l}{ }^{2} \text { Department of Biodiversity } \\
\text { Conservation, Eastern Cape } \\
\text { Parks and Tourism Agency, } \\
\text { East London, South Africa }\end{array}$} \\
\hline \multicolumn{2}{|c|}{$\begin{array}{l}{ }^{3} \text { Centre for Wildlife } \\
\text { Management, University of } \\
\text { Pretoria, South Africa }\end{array}$} \\
\hline \multicolumn{2}{|c|}{$\begin{array}{l}\text { Correspondence to: } \\
\text { Colleen Downs }\end{array}$} \\
\hline \multicolumn{2}{|c|}{$\begin{array}{l}\text { Email: } \\
\text { downs@ukzn.ac.za }\end{array}$} \\
\hline \multicolumn{2}{|c|}{$\begin{array}{l}\text { Postal address: } \\
\text { Private Bag X01, Scottsville } \\
\text { 3209, South Africa }\end{array}$} \\
\hline \multicolumn{2}{|c|}{$\begin{array}{l}\text { Dates: } \\
\text { Received: } 04 \text { July } 2014 \\
\text { Accepted: } 07 \text { Jan. } 2015 \\
\text { Published: } 18 \text { May } 2015\end{array}$} \\
\hline \multicolumn{2}{|c|}{$\begin{array}{l}\text { How to cite this article: } \\
\text { Pfeiffer, M.B., Venter, } \\
\text { J.A. \& Downs, C.T., 2015, } \\
\text { 'Foraging range and habitat } \\
\text { use by Cape Vulture Gyps } \\
\text { coprotheres from the } \\
\text { Msikaba colony, Eastern } \\
\text { Cape province, South } \\
\text { Africa', Koedoe 57(1), Art. } \\
\text { \#1240, } 11 \text { pages. http:// } \\
\text { dx.doi.org/10.4102/koedoe. } \\
\text { v57i1.1240 }\end{array}$} \\
\hline \multicolumn{2}{|c|}{$\begin{array}{l}\text { Copyright: } \\
\text { (C) 2015. The Authors. } \\
\text { Licensee: AOSIS } \\
\text { OpenJournals. This work is } \\
\text { licensed under the Creative } \\
\text { Commons Attribution } \\
\text { License. }\end{array}$} \\
\hline \multicolumn{2}{|l|}{ Read online: } \\
\hline 回战回 & $\begin{array}{l}\text { Scan this QR } \\
\text { code with your } \\
\text { smart phone or } \\
\text { mobile device } \\
\text { to read online. }\end{array}$ \\
\hline
\end{tabular}

Authors:

Morgan B. Pfeiffer

Affiliations

${ }^{1}$ School of Life Sciences, University of KwaZulu-Natal, Parks and Tourism Agency,

${ }^{3}$ Centre for Wildlife Management, University of Correspondence to: Email: Private Bag X01, Scottsville

Dates:

Accepted: 07 Jan. 2015

J.A. \& Downs, C.T., 2015,

'Foraging range and habitat \#1240, 11 pages. http:// dx.doi.org/10.4102/koedoe.

Licensee: AOSIS

OpenJournals. This work is Commons Attribution License.

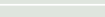
to read online.
Despite the extent of subsistence farmland in Africa, little is known about endangered species that persist within them. The Cape Vulture (Gyps coprotheres) is regionally endangered in southern Africa and at least $20 \%$ of the population breeds in the subsistence farmland area previously known as the Transkei in the Eastern Cape province of South Africa. To understand their movement ecology, adult Cape Vultures $(n=9)$ were captured and fitted with global positioning system/global system for mobile transmitters. Minimum convex polygons (MCPs), and $99 \%$ and $50 \%$ kernel density estimates (KDEs) were calculated for the breeding and nonbreeding seasons of the Cape Vulture. Land use maps were constructed for each 99\% KDE and vulture locations were overlaid. During the non-breeding season, ranges were slightly larger (mean $\left.[ \pm \mathrm{SE}] \mathrm{MCP}=16887 \mathrm{~km}^{2} \pm 366 \mathrm{~km}^{2}\right)$ than the breeding season $\left(\mathrm{MCP}=14707 \mathrm{~km}^{2} \pm\right.$ $2155 \mathrm{~km}^{2}$ ). Breeding and non-breeding season MCPs overlapped by a total of $92 \%$. Kernel density estimates showed seasonal variability. During the breeding season, Cape Vultures used subsistence farmland, natural woodland and protected areas more than expected. In the non-breeding season, vultures used natural woodland and subsistence farmland more than expected, and protected areas less than expected. In both seasons, human-altered landscapes were used less, except for subsistence farmland.

Conservation implications: These results highlight the importance of subsistence farmland to the survival of the Cape Vulture. Efforts should be made to minimise potential threats to vultures in the core areas outlined, through outreach programmes and mitigation measures. The conservation buffer of $40 \mathrm{~km}$ around Cape Vulture breeding colonies should be increased to $50 \mathrm{~km}$.

\section{Introduction}

Africa has been inhabited by humans for over 300000 years (Fisher et al. 2013; Sheehan \& Sanderson 2012). Within that time, communal grazing of livestock, human-induced fires, depletion of indigenous forests and urbanisation have altered many landscapes (Lawes, Griffiths \& Boudreau 2007; Sheehan \& Sanderson 2012; Skead 1987; Vetter \& Bond 2012). Although heavily humanaltered landscapes are often degraded, endangered species can persist in these environments (McKee et al. 2004; Phipps et al. 2013b).

One opportunistic animal guild that has coexisted with humans for centuries is the vulture (Haas \& Mundy 2013; Moleón et al. 2014). Vultures perform an important ecosystem service by consuming carcasses. Vultures recycle nutrients, reduce the potential for the spread of infectious diseases, and provide a carbon-neutral waste removal service (Dupont et al. 2012; Prakash et al. 2003; Ogada et al. 2012b). In some cultures, vultures are highly revered and, for example, are used to ritually dispose of human corpses (Haas \& Mundy 2013). However, 61\% of vulture species worldwide are vulnerable to extinction from a variety of threats (Ogada et al. 2012a). Understanding how vultures persist in human-altered landscapes will provide information on where and how to focus conservation efforts on a regional and global scale.

The Cape Vulture (Gyps coprotheres), a colonial nesting scavenger, is endemic to southern Africa. It is listed as 'vulnerable' on the Red List of Threatened Species of the International Union for Conservation of Nature and Natural Resources (IUCN) and as 'endangered' in the Eskom Red Data Book of Birds of South Africa, Lesotho and Swaziland (BirdLife International 2013).

At least $20 \%$ of the global population breeds in the former Bantustan homeland of the Transkei in the Eastern Cape province of South Africa (BirdLife International 2013; Boshoff, Piper \& Michael 2009; Piper 1994). This area was created under segregation laws of the former apartheid government of South Africa and is characterised by high human densities and subsistence 
farmland (Kepe 1997; Shackleton et al. 1991; Statistics South Africa 2011). In this area, every resident has access to communal grazing land and livestock numbers are not restricted (Vetter \& Bond 2012).

Most of the Cape Vulture breeding colonies in the former Transkei are located in formal protected areas or Important Bird Areas (IBAs) (BirdLife South Africa 2013). Two of the three protected areas, namely Collywobbles Vulture Colony (IBA SA088) and Pondoland Cape Vulture Colonies (IBA SA126), were designated as IBAs specifically to promote the conservation of this threatened species (BirdLife International 2014a; BirdLife International 2014b). However, foraging vultures are rarely confined to protected areas and are thus exposed to numerous threats elsewhere (Bamford et al. 2007; Phipps et al. 2013a). For example, Cape Vultures are illegally killed for the traditional medicine market and are negatively impacted by power line infrastructure in the Eastern Cape (Boshoff et al. 2011; Mander et al. 2007). Poisoned carcasses, resulting in mass vulture mortalities, appear to be an infrequent occurrence in subsistence farmland areas, but do occur on commercial farms (Brown \& Piper 1988)

A possible benefit to vultures in the former Transkei is the relatively high livestock mortality rates compared to commercial farming areas, which results in an abundance of carrion (Boshoff et al. 2009; Vernon 1998). Furthermore, the landscape in the former Transkei contains numerous suitable cliffs on which Cape Vultures roost and breed (Mundy et al. 1992; Piper \& Ruddle 1986). Despite having knowledge of the potential threats and perceived benefits for Cape Vultures, knowledge of the movement ecology and detailed demographic information of Cape Vultures in this area is lacking.

BirdLife South Africa, the Endangered Wildlife Trust (EWT) and a number of bird specialists recommend $40 \mathrm{~km}$ buffers around Cape Vulture breeding colonies as conservation priority areas to prevent mortalities from wind turbines and hazardous power infrastructure development (Boshoff \& Minnie 2011; Retief et al. 2013). Breeding Cape Vultures of the southern node population are known to forage and move extensively within this range (Boshoff \& Minnie 2011; Boshoff, Robertson \& Norton 1984; Brown \& Piper 1988; Robertson \& Boshoff 1986).

Breeding vultures that forage within $40 \mathrm{~km}$ of the colony are better able to relieve their partner of parenting duties so that both can forage on the same day (Ruxton \& Houston 2002). Vultures that forage in this manner are thought to have higher breeding success because of a higher food delivery rate to the chick (Ruxton \& Houston 2002). However, telemetry-based Cape Vulture studies in other regions have indicated that both breeding and non-breeding Cape Vultures forage considerably farther than $40 \mathrm{~km}$ from the breeding colony, which may weaken the conservation goals of the colony buffers (Bamford et al. 2007; Phipps et al. 2013b).
Foraging ranges of vultures may be influenced by the surrounding land uses or presence of vulture feeding sites. Vulture feeding sites (vulture restaurants) provide an uncontaminated, regular supply of carrion for vultures, which aims to prevent mortalities from food shortages and poisonings (Piper, Boshoff \& Scott 1999). Most operate on commercial farms in South Africa (EWT and Ezemvelo KwaZulu-Natal [KZN] Wildlife unpublished data). In the Eastern Cape, all active Cape Vulture breeding colonies are in or near subsistence farmland with few vulture feeding sites, but the degree of subsistence farmland use by Cape Vultures remains unknown.

The aim of this study was to document the foraging range and habitat use of adult Cape Vultures in the former Transkei from a colony in the Mkambati Nature Reserve. One intention of the study was to test if $40 \mathrm{~km}$ buffers around southern Cape Vulture breeding colonies are adequate for their intended conservation purposes. The size, shape and habitat use in the overall foraging and core areas were investigated and possible seasonal differences quantified. Seasons were separated into either breeding or non-breeding season.

Adult vultures were expected to conduct fewer foraging trips during the early breeding season and incubation (Kendall et al. 2014; Spiegel et al. 2013). Breeding behaviour may concentrate Cape Vulture movements to areas that maximise the success of foraging trips. These areas would be ideal to identify for conservation planning. Additionally, a small proportion of Cape Vultures may migrate from the eastern part of the Eastern Cape to the west in the nonbreeding season (Boshoff et al. 2009). If this migration occurs, it would be important to isolate any corridors or flight paths. Vulture movements may be influenced by the availability of resources across the landscape. Therefore, resource selection by the vultures was thought to differ with land use and season (Murn \& Anderson 2008; Vernon 1998). The location of the study vulture colony provides a unique opportunity to investigate the vultures' use of subsistence and commercial farmland, as both land uses are present within $100 \mathrm{~km}$ of the colony.

\section{Methods}

Study area

The entire former Transkei (approximately $27^{\circ} \mathrm{E}-30^{\circ} \mathrm{E}$ and $33^{\circ} \mathrm{S}-30^{\circ} \mathrm{S}$ ) is located in the Eastern Cape and KwaZuluNatal provinces of South Africa (Boshoff et al. 2009). The Indian Ocean coastal belt, savanna and grassland are the three major biomes in the study area (Mucina et al. 2006). Ngongoni grass (Aristida junciformis) dominates the savanna and grassland biomes, while the Indian Ocean coastal belt supports patches of species-rich sour grasslands (Mucina et al. 2006). The dominant herbivores in the study area are domestic livestock (either for subsistence or commercial purposes) and wild ungulates in fenced protected areas (Boshoff \& Vernon 1980; Shackleton et al. 1991). 


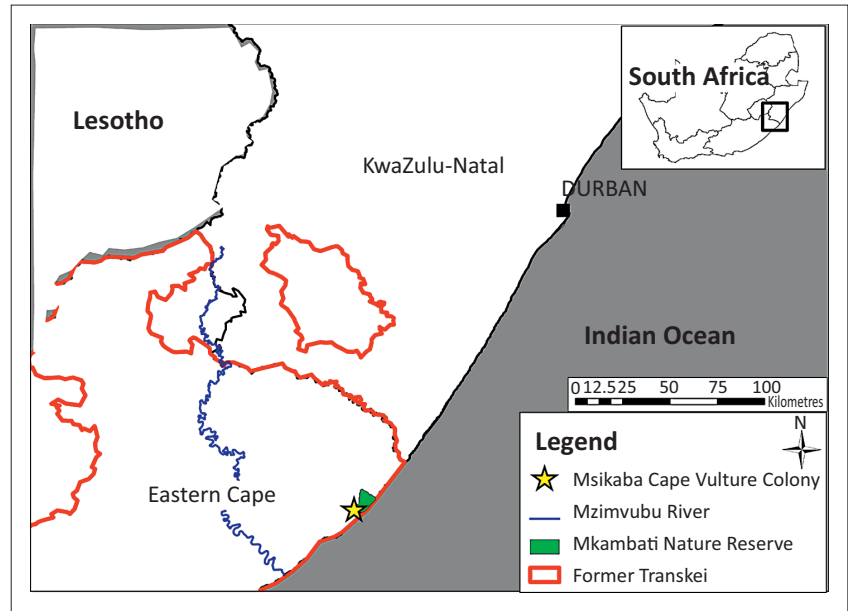

FIGURE 1: Location of the former Transkei, Mkambati Nature Reserve and the Msikaba Cape Vulture breeding colony in the Eastern Cape province of South Africa.

The Msikaba Cape Vulture colony $\left(31^{\circ} 16^{\prime} \mathrm{S}, 2^{\circ} 59^{\prime} \mathrm{E}\right.$; $200 \mathrm{~m}$ a.s.l.; Figure 1) is located on cliffs formed by the Msikaba River in the Mkambati Nature Reserve (Boshoff \& Minnie 2011; Piper \& Ruddle 1986). At least 170 Cape Vulture pairs breed regularly within the Mkambati Nature Reserve (Botha et al. 2012). Vulture breeding activity was first documented at Msikaba in 1984; however, breeding attempts along the Mtentu River, the northern boundary of the Mkambati Nature Reserve, were first documented in the mid-1970s (Piper \& Ruddle 1986). Annual rainfall is about $1200 \mathrm{~mm}$ and the difference in monthly mean temperature is less than $6{ }^{\circ} \mathrm{C}$ along the coast (Shackleton et al. 1991).

\section{Cape Vulture captures and marking}

A $9 \mathrm{~m} \times 6 \mathrm{~m} \times 3 \mathrm{~m}$ wooden-framed walk-in cage trap (Diekmann et al. 2004) was constructed at the Cape Vulture feeding site at the Mkambati Nature Reserve. The walls of the cage consisted of wire mesh $(100 \mathrm{~mm})$ reinforced with steel cable. Translucent shade cloth (50\% opaqueness) was attached to the walls to prevent injuries to the vultures. Construction and baiting of the trap with ungulate carcasses from the Mkambati Nature Reserve commenced at least 7 months before capture attempts.

Each vulture captured was fitted with a unique metal South African Bird Ringing Unit (SAFRING) ring and patagial tags on both wings. Adults $(n=9)$ were identified by plumage and eye colour (Mundy 1982). Avi-Track (Pietermaritzburg, South Africa) global positioning system (GPS)/global system for mobile (GSM) transmitters were attached as backpacks $(n=3)$ and pelvic mounts $(n=3)$ using Teflon ${ }^{\circledR}$ ribbon. Cellular Tracking Technologies (CTT) 1100 GPS/GSM transmitters (Somerset, Pennsylvania, USA) were attached as backpacks $(n=2)$ and as a pelvic mount $(n=1)$. The average weights of the Avi-Track and CTT units were $97 \mathrm{~g}$ and $136 \mathrm{~g}$ respectively, which is less than $1 \%$ of the average weight of an adult Cape Vulture (Piper 2005).

\section{Data collection}

The Avi-Track transmitters were programmed to record the GPS location of the vulture, direction of travel and speed at least six times a day in $2 \mathrm{~h}$ intervals from 06:00 to 18:00. The CTT transmitters were programmed to record the GPS location of the vulture, horizontal dilution of precision, fix quality, direction of travel, speed and altitude every $15 \mathrm{~min}$ from sunrise to sunset. For comparison with the Avi-Track units, a subsample of the CTT data was created by using one data point every $2 \mathrm{~h}$ for a total of six GPS locations a day. The first and last point of the day (which changed with day length) were used in addition to three points during the day, which were at least $2 \mathrm{~h}$ apart.

\section{Data analysis}

The vulture transmitter data were entered into ArcGIS 9.3 (ESRI, www.esri.com) and projected to the Universal Transverse Mercator (UTM) (WGS [World Geodetic System] 1984 UTM Zone 35S). To determine if an asymptote was reached during each season, the minimum convex polygons (MCPs) were plotted in relation to the number of GPS locations. Visually, asymptotes were identified and vultures that reached asymptotes were used for further analyses.

Although widely criticised, MCP is the most commonly used home range estimator. It entails drawing the smallest polygon that incorporates all of the animal's locations (Powell 2000). The MCPs $(100 \%)$ were calculated for each vulture in both breeding and non-breeding seasons and tested for differences. The breeding season data included all fixes from May to October 2013, while the non-breeding season data included fixes from November 2012 to April 2013 (Mundy et al. 1992). The mean egg-laying period is May to June, with chicks hatching between July and August. Fledglings can be dependent on their parents until October or November, and even into December (Mundy et al. 1992; Piper 1994). The percentage of MCP overlap was calculated for the two seasons.

Since MCPs generally include areas that are not visited by the vulture, kernel density estimates (KDEs) were used to identify high density areas of vultures. In previous studies, 95\% KDEs were found to produce numerous fragmented areas; hence 99\% KDEs were used (Blundell, Maier \& Debevec 2001; Phipps et al. 2013b). Fifty percent KDEs were used to identify core areas. Both $99 \%$ and 50\% KDEs were calculated for the breeding and non-breeding seasons and tested for seasonal differences. All KDEs were calculated using bivariate fixed kernels with a reference bandwidth. Least-squares cross validation calculations for KDEs could not be used because of numerous identical roosting locations. The raster cell size was $1000 \mathrm{~m} \times 1000 \mathrm{~m}$. Both MCP and KDE contours were produced using the Home Range Tools (HRT) extension for ArcGIS (Rodgers et al. 2007).

Mann-Whitney tests were used to determine differences in foraging range size (MCP, 99\% KDEs, 50\% KDEs) and season (breeding vs non-breeding). $P$-values $<0.05$ were 
read as significant. Statistical analyses were conducted in STATISTICA (StatSoft 2006).

\section{Habitat use and GPS tracking}

A land use map was created using the South African National Land Cover Database merged with all the protected areas of South Africa and Lesotho (South African National Botanical Institute [SANBI] 2000; IUCN and United Nations Environment Programme's World Conservation Monitoring Centre [UNEP-WCMC] 2014). The 41 original South African National Land Cover Database land use categories were compressed into six land use classes: urban centres, village communities, natural woody vegetation, tree plantations, commercial farmland and subsistence farmland (Table A1). As the original map did not illustrate livestock grazing land (only cultivated land), land use classes such as 'natural grassland' were separated into commercial or subsistence farmland based on their location to the former political boundaries of the Transkei (Figure A1).

Tree plantations and natural woody vegetation were separated because of the level of human transformation in these areas. To account for urban and suburban sprawl, $2 \mathrm{~km}$ buffers were placed around the urban and village layers. The polygon layer was converted into a raster with a cell size of $1800 \mathrm{~m}$. The raster assigned one land use value to each cell, based on the cell centre. Analysis was limited by the resolution of spatial data available, but was compensated appropriately using buffers and the unbiased method of assigning a land use value based on the cell's centre.

The 99\% KDEs of pooled Cape Vulture locations from the breeding and non-breeding seasons were clipped to the final categorised land use map, excluding areas that extended into the Indian Ocean, since vultures do not fly above oceans (pers. obs.). For each 99\% KDE, areas of all land uses were calculated $\left(\mathrm{km}^{2}\right)$. The number of vulture GPS locations within each land use was also calculated. Both procedures were conducted with Hawth's Analysis Tools (Beyer 2004). Habitat use in proportion to availability, considering each land use separately, was tested using the Bonferroni Z-statistic in Microsoft Excel (Byers, Steinhorst \& Krausman 1984).

In total, 34 Cape Vultures (including 1 recapture) were captured in 2012 and 2013, during the non-breeding season. The GPS locations of birds were highly autocorrelated, with a mean Schoener's index value of $0.10 \pm 0.07$. This index detected that the individual's GPS locations were not independent of each other, which may result in underestimating home range estimates (Swinhart \& Slade 1985). To correct this, all data were rescaled to unit variance using Home Range Tools (Rodgers et al. 2007). The reference bandwidth for both seasons across all individuals was $0.34 \pm 0.02$ for KDEs.

\section{Results}

Nine transmitters recorded location data for $277 \pm 72$ days. Of the vultures fitted with transmitters, five reached an MCP

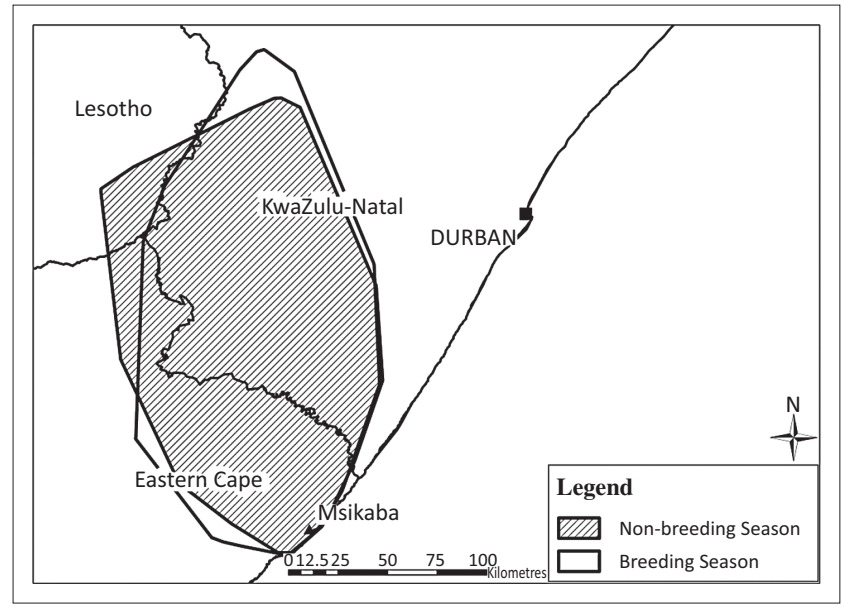

FIGURE 2: The combined minimum convex polygons of adult Cape Vultures (Gyps coprotheres) in the breeding $(n=5)$ and non-breeding seasons $(n=4)$ captured at the Msikaba Cape Vulture colony in the Eastern Cape, South Africa.

asymptote during the breeding season and four during the non-breeding season (Figure A2). The average number of GPS locations for the breeding and non-breeding seasons were $717 \pm 122(n=5)$ and $820 \pm 123(n=4)$ respectively. The number of fixes required for MCPs to become constant varied, but generally, transmitters with fewer than 300 GPS locations were found to be insufficient. Some vultures were tracked for both seasons, while other transmitters were deployed later in the season, or failed. Three transmitters stopped working for unknown reasons (birds were resighted alive) before 300 GPS locations were collected; these data were excluded from the analyses. Two transmitters only collected data for one season (X023 and X022). Of the vultures used for analysis, two (X027 and X023) were confirmed to have successfully raised chicks in 2013. One vulture (X022) was observed at a nesting site arranging nesting material with its partner, but did not breed.

\section{Foraging ranges}

General movements of the Cape Vultures occurred from the breeding colony in the south to the south-western part of the KwaZulu-Natal province. No vultures travelled south of the Mzimvubu River mouth during the tracking period. The pooled breeding season MCP overlapped $92 \%$ with the nonbreeding season MCP (Figure 2). The mean MCP during the breeding season was $14707 \mathrm{~km}^{2} \pm 2155 \mathrm{~km}^{2}(n=5$, median $=$ $13282 \mathrm{~km}^{2}$ ). The mean MCP during the non-breeding season was $16887 \mathrm{~km}^{2} \pm 366 \mathrm{~km}^{2}\left(n=4\right.$, median $\left.=16602 \mathrm{~km}^{2}\right)$. There was no significant difference between individual MCPs (Mann-Whitney test, $Z=-0.49, P=0.62$ ).

Individual 99\% KDEs were not significantly larger in the non-breeding season (Mann-Whitney test, $Z=-0.73, P=$ 0.46 ), nor were the $50 \%$ KDEs (Mann-Whitney test, $Z=-1.71$, $P=0.09$ ). When Cape Vulture GPS locations were pooled together, MCPs and 99\% KDEs were only slightly larger in the breeding season than the non-breeding season (Table 1). Pooled 50\% KDEs were also only slightly larger $\left(908 \mathrm{~km}^{2}\right)$ in the non-breeding season (Figure 3). Minimum convex polygons and $99 \%$ KDEs were similar across the breeding 
TABLE 1: Home range estimates for adult Cape Vultures (Gyps coprotheres) captured at Mkambati Nature Reserve, Eastern Cape, South Africa.

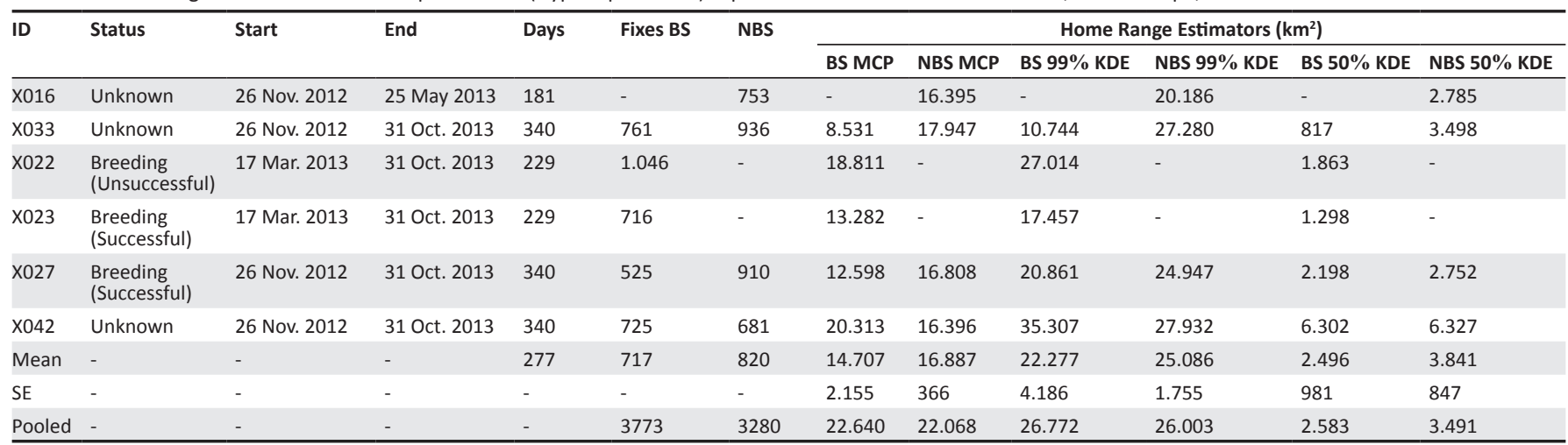

$\mathrm{ID}$, identification; SE, standard deviation; BS, breeding season; NBS, non-breeding season; MCP, minimum convex polygons; KDE, kernel density estimate.

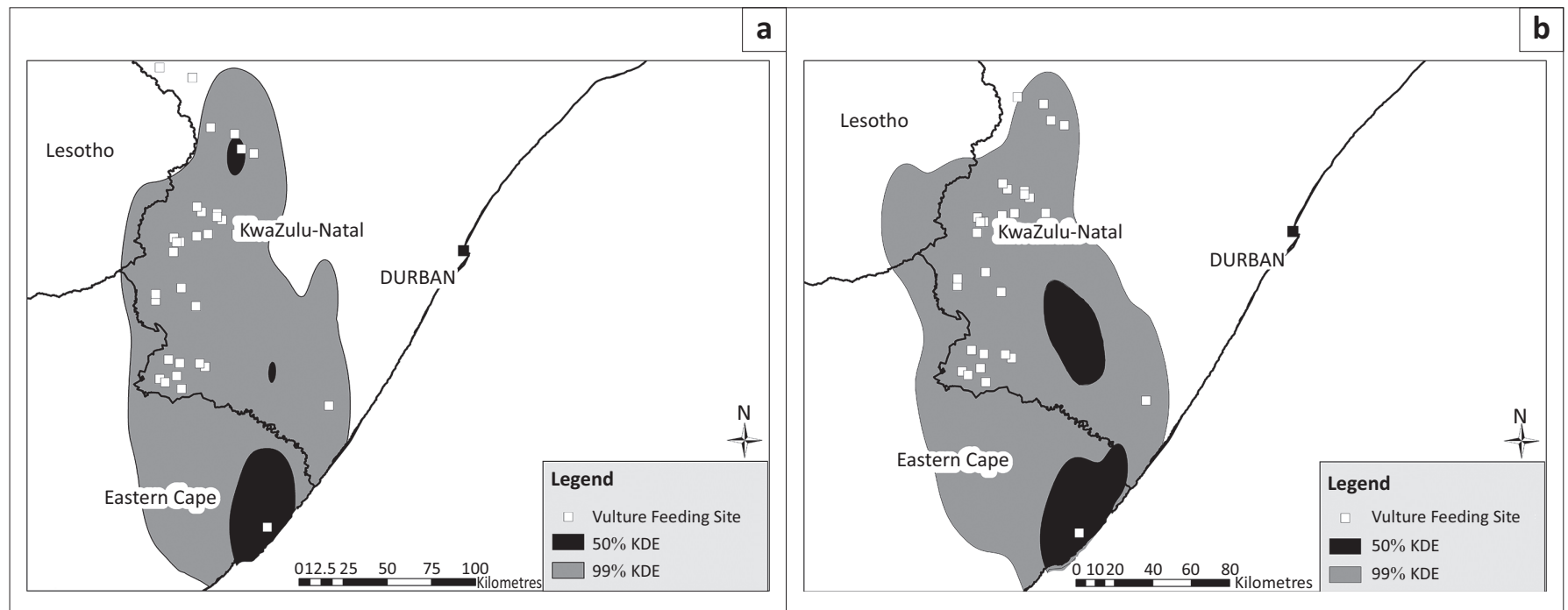

KDE, kernel density estimate.

FIGURE 3: Combined kernel density estimates for adult Cape Vultures (Gyps coprotheres) in the (a) breeding $(n=5)$ and (b) non-breeding season ( $n=4)$ captured at the Msikaba Cape Vulture colony, Eastern Cape, South Africa. Kernel density estimate areas that extended into the Indian Ocean were removed as vultures cannot forage there.

and non-breeding seasons, while the number and size of $50 \%$ KDEs differed slightly.

The maximum radius of the $50 \% \mathrm{KDE}$ around the Msikaba Cape Vulture colony was $46 \mathrm{~km}$ during the breeding season. The other two core $50 \%$ KDEs during the breeding season had smaller radii $(7 \mathrm{~km}$ and $11 \mathrm{~km})$ and were located north of the breeding colony (Figure 3). The northernmost 50\% KDE during the breeding season was mainly created by one bird (X042), which was not recorded at a breeding site at Msikaba. In the non-breeding season, there were only two core $50 \%$ KDEs areas. During the non-breeding season, the maximum radius from the colony to the edge of the $50 \%$ $\mathrm{KDE}$ was $52 \mathrm{~km}$. The 50\% KDE not located around the breeding colony had a radius of $29 \mathrm{~km}$ in the non-breeding season.

\section{Habitat use}

When vulture locations were pooled, habitats were not selected in proportion to their availability. Habitat selected by vultures differed between the breeding and non-breeding seasons (Table 2; Figure 4). Cape Vultures used subsistence farmland and natural woody vegetation more than expected in both the breeding and non-breeding season (Table 2). Protected areas were used in a greater proportion during the breeding season, while during the non-breeding season protected areas were used less than their availability in the $99 \%$ KDEs (Table 2). In both seasons, commercial farmland, plantations, urban centres and villages were used less than their availability in the $99 \%$ KDEs of the vultures (Table 2 ).

\section{Discussion}

This study highlights the importance of subsistence farmland, rather than commercial farmland, as foraging habitat for Cape Vultures from the Msikaba colony. Although the results presented here are from a small and restructured sample size $(n=9)$, they illustrate the seasonal foraging and habitat selection patterns of the Cape Vulture in the southern node population.

Adult vultures from the Msikaba colony exhibited a welldefined foraging range. The tagged vultures did not participate in westerly migratory behaviour as previously 
TABLE 2: Habitat availability in pooled $99 \%$ kernel density estimate based on the reclassified land use map. Bonferroni confidence intervals were used to determine Cape Vulture habitat use in pooled $99 \%$ kernel density estimate.

\begin{tabular}{|c|c|c|c|c|c|c|c|}
\hline Season & Habitat type & Contribution $\%$ & Area $\left(\mathrm{km}^{2}\right)$ & $P_{\mathrm{i}}$ & $P_{\mathrm{i} 0}$ & Bonferroni Cl & Conclusion \\
\hline \multirow[t]{7}{*}{ Non-breeding $\left(23877 \mathrm{~km}^{2}\right)$} & Commercial Farmland & 26 & 6322 & 0.147 & 0.265 & $0.131<P<0.163^{*}$ & Not Preferred \\
\hline & Subsistence Farmland & 17 & 4077 & 0.241 & 0.171 & $0.221<P<0.260 *$ & Preferred \\
\hline & Woody Vegetation & 8 & 1886 & 0.273 & 0.079 & $0.252<P<0.293^{*}$ & Preferred \\
\hline & Plantation & 5 & 1098 & 0.006 & 0.046 & $0.002<P<0.009 *$ & Not Preferred \\
\hline & Urban & 4 & 1067 & 0.018 & 0.045 & $0.012<P<0.024 *$ & Not Preferred \\
\hline & Village & 28 & 6772 & 0.226 & 0.284 & $0.207<P<0.245^{*}$ & Not Preferred \\
\hline & Protected Area & 11 & 2655 & 0.09 & 0.111 & $0.077<P<0.103 *$ & Not Preferred \\
\hline \multirow[t]{7}{*}{ Breeding (24 $664 \mathrm{~km}^{2}$ ) } & Commercial Farmland & 28 & 6977 & 0.136 & 0.283 & $0.120<P<0.151 *$ & Not Preferred \\
\hline & Subsistence Farmland & 15 & 3799 & 0.251 & 0.154 & $0.231<P<0.271 *$ & Preferred \\
\hline & Woody Vegetation & 10 & 2492 & 0.286 & 0.101 & $0.265<P<0.306^{*}$ & Preferred \\
\hline & Plantation & 5 & 1174 & 0.004 & 0.048 & $0.001<P<0.007^{*}$ & Not Preferred \\
\hline & Urban & 5 & 1318 & 0.013 & 0.053 & $0.008<P<0.018^{*}$ & Not Preferred \\
\hline & Village & 27 & 6552 & 0.186 & 0.266 & $0.169<P<0.204^{*}$ & Not Preferred \\
\hline & Protected Area & 10 & 2352 & 0.124 & 0.095 & $0.109<P<0.139 *$ & Preferred \\
\hline
\end{tabular}

Non-breeding season $(n=3269)$

Breeding season $(n=3578)$

B, 2.69 .

$P_{\mathrm{i}}$, actual proportion of usage; $P_{\mathrm{io}}$ expected proportion of usage; Bonferroni $\mathrm{Cl}$, Bonferroni confidence intervals.

$*$, a significant difference at $P<0.05$.

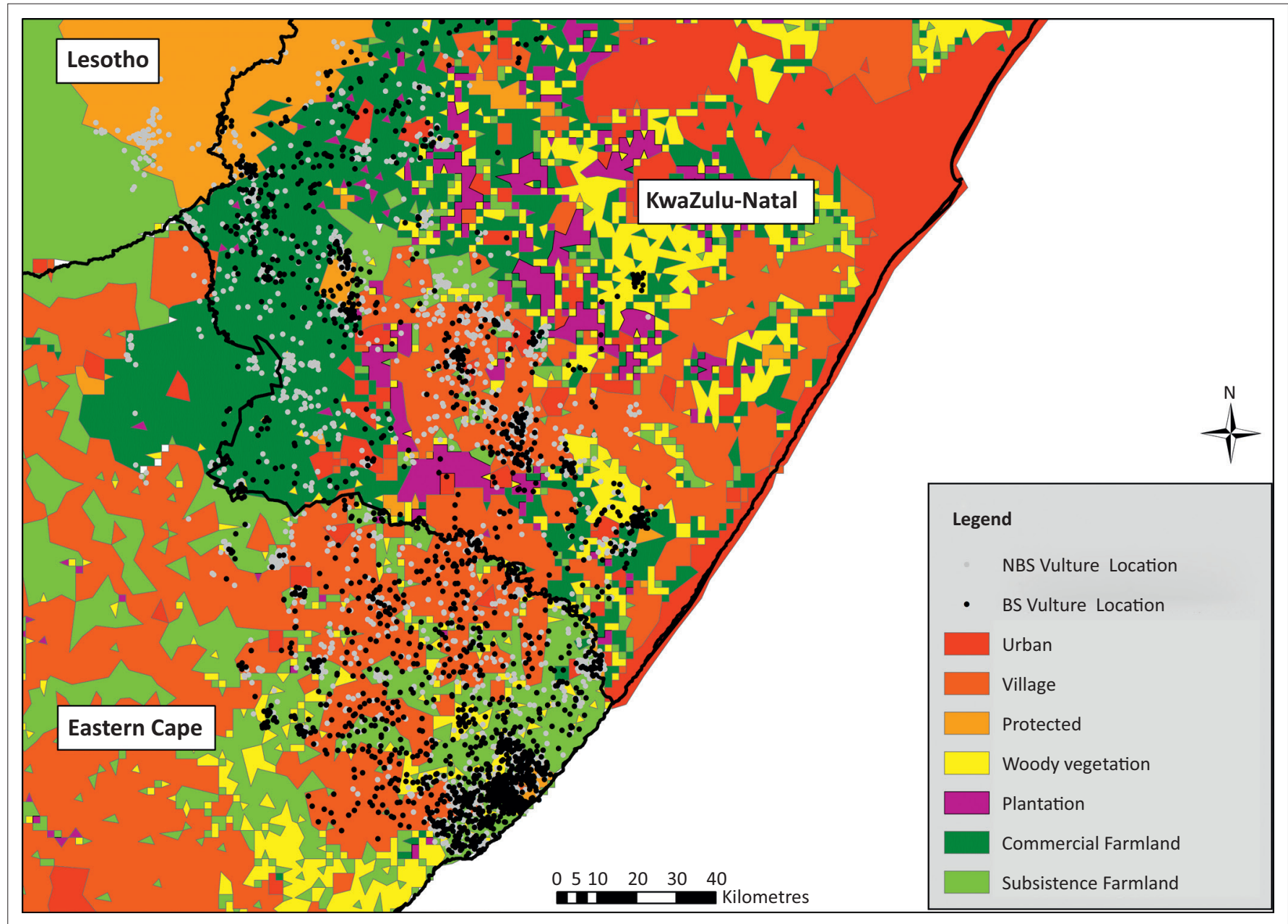

NBS, non-breeding season; BS, breeding season.

FIGURE 4: Cape Vulture (breeding and non-breeding season) locations overlaid on the land use map used for habitat analysis.

reported by Boshoff et al. (2009). Foraging ranges calculated as MCPs were found to overlap considerably in the breeding and non-breeding seasons. Other studies have also observed that the distance covered by vultures during the breeding season is similar to the non-breeding season, but foraging trips occurred less frequently in the early breeding season and during incubation (Bamford, Monadjem \& Hardy 2007; Kendall et al. 2014; Spiegel et al. 2013). The 50\% core area around the breeding colony was oval shaped and extended towards KwaZulu-Natal with a radius ranging $17 \mathrm{~km}-46 \mathrm{~km}$ 
during the breeding season. During the non-breeding season the $50 \% \mathrm{KDE}$ around the colony increased to a maximum radius of $52 \mathrm{~km}$. The size of the core area around the colony was therefore larger than the proposed $40 \mathrm{~km}$ buffer (Boshoff \& Minnie 2011).

As the home range represents an area 'traversed by the individual in its normal activities of food gathering, mating and caring for young' (Burt 1943), a smaller range may be explained by the abundance of food or suitable roosts in the environment. Formal protected areas were used more than expected during the breeding season, possibly because breeding sites were located in protected areas, not because there was more carrion available. As adult Cape Vultures were captured in the Mkambati Nature Reserve and two vultures were confirmed successful breeders, more time was spent at this locale.

Cape Vultures used formal protected areas less during the non-breeding season, while natural woody vegetation and subsistence farmlands were preferred. Use of natural woody vegetation by the vultures may have been misinterpreted because of the scale of the habitat classifications, as cliffs were not distinguished in the habitat classifications. Vultures did not necessarily use the woody vegetation, but the steep cliffs located above them, as roosting sites. Roost sites in the study area were typically located on isolated cliff faces with indigenous forest at the base (Boshoff \& Minnie 2011; pers. obs.).

The two 50\% KDEs created during the non-breeding season were both located in subsistence farmland that contains only one formal (registered with EWT or Ezemvelo KZN Wildlife) vulture feeding site, which was located in the Mkambati Nature Reserve. Other studies have found that African vultures use subsistence farmland less (Bamford et al. 2007; Bamford et al. 2009). This could be explained by different livestock carcass management (burning or burying) or overharvesting of forest resources, which prevent tree-nesting vulture species from inhabiting these areas (Monadjem \& Garcelon 2005). In the former Transkei, carrion may be more readily available because of inadequate animal husbandry and abundant tick-borne diseases (Shackleton et al. 2013). Strong cultural traditions may provide another scavenging opportunity for vultures: during traditional ceremonies, local amaXhosa people slaughter and butcher animals, the leftovers of which are discarded for vultures and other scavengers (Pfeiffer pers. obs.).

Commercial farmland areas were used less than expected during both seasons, despite the presence of formal vulture feeding sites. However, the northernmost 50\% KDE in the breeding season was located near multiple vulture feeding sites. (One feeding site was located inside the northernmost $50 \% \mathrm{KDE}$.) The number of fixes a day in the current study (six a day including roosting locations) may have been insufficient to identify feeding events, which may have resulted in underestimating the use of vulture feeding sites. Furthermore, Cape Vultures can be grounded at roost sites for long periods of time because of adverse soaring conditions. Accordingly, these results may overestimate roosting locations and underestimate feeding events (Monsarrat et al. 2013; Spiegel et al. 2013). Future research should use higher resolution GPS data in order to identify feeding events and then calculate habitat use.

\section{Conservation implications}

The findings presented here highlight the relatively small foraging ranges of adult Cape Vultures from the Msikaba colony and their extensive use of subsistence farmland. Conservation efforts should focus on mitigating threats to vultures in the $50 \%$ KDEs, which are mainly located in subsistence farmland. Three local municipalities (Ingquza Hill, Mbizana and Umzimkhulu) were represented in both the breeding and non-breeding season 50\% KDEs. On-theground conservation projects by provincial staff and relevant non-government organisations should be conducted in these areas. As some Cape Vulture core areas differed between the breeding and non-breeding seasons, other local municipal districts could be targeted based on the time of the year. During the breeding season (May to October), Impendle, uMngeni and Mpofana local municipalities were represented in the 50\% KDEs. In the non-breeding season (November April), Hibiscus Coast, Ezinqoleni, uMuziwabantu and Ubuhlebezwe local municipalities were represented and should be targeted for conservation projects during these months.

Based on these results, it is recommended that buffers around Cape Vulture colonies in the southern node population be increased from $40 \mathrm{~km}$ to $50 \mathrm{~km}$. For Cape Vulture roost sites, $40 \mathrm{~km}$ buffers appear to be sufficient. In certain areas where this may be in conflict with development, a combination of GPS tracking data and risk assessment modelling should be used to construct conservation priority areas (Katzner et al. 2012).

\section{Conclusion}

Although vultures are far-ranging foragers that will never be fully secure within protected areas, it is essential to identify and proclaim conservation buffers. Tracking of a small sample of adult Cape Vultures from one colony has successfully identified the main foraging areas of vultures from that colony, and perhaps in the region. These areas can be targeted in focused strategic action plans aimed at avoiding or reducing the mortality of vultures. It will only be with the collaboration of communities, policy makers, conservation organisations and provincial governments that this regionally endangered vulture species will survive.

\section{Acknowledgments}

The Gay Langmuir bursary, the Rufford Grant, the University of KwaZulu-Natal, and the Eastern Cape Parks and Tourism Agency are thanked for research funding. Thank you to V. Mapiya and the staff of the Mkambati Nature Reserve 
for field assistance. The Mazda Wildlife Fund is thanked for vehicle assistance. J. Greeff, B. Hoffman, S. Kruger, S. McPherson, M. and K. Bowker, C. and K. Nelson, D. Berens, M. Witteveen, D. Allan, S. Heuner, A. Botha and VulPro are thanked for helping with the capture of the vultures. Field work was conducted in accordance to the laws of South Africa. Permits for vulture captures were granted by the Department of Environmental Affairs (TOPS Permit Nr. 05052) and approved by the ethics committee of the University of KwaZulu-Natal.

\section{Competing interests}

The authors declare that they have no financial or personal relationships which may have inappropriately influenced them in writing this article.

\section{Authors' contributions}

M.B.P. (University of KwaZulu-Natal) was the project leader. M.B.P., J.A.V. (Department of Biodiversity Conservation) and C.T.D. (University of KwaZulu-Natal) conceived and designed the experiments. M.B.P was responsible for performing the experiments and analysing the data. M.B.P., J.A.V. and C.T.D. wrote the article.

\section{References}

Bamford, A.J., Diekmann, M., Monadjem, A. \& Mendelsohn, J., 2007, 'Ranging behaviour of Cape Vultures Gyps coprotheres from an endangered population in Namibia', Bird Conservation International 17(4), 331-339. http://dx.doi. org/10.1017/S0959270907000846

Bamford, A.J., Monadjem, A. \& Hardy, I.C.W., 2009, 'Nesting habitat preference of the African White-backed Vulture Gyps africanus and the effects of anthropogenic disturbance', Ibis 151(1), 51-62. http://dx.doi.org/10.1111/j.1474919X.2008.00878.x

Beyer, H.L., 2004, Hawth's Analysis Tools for ArcGIS, viewed n.d., from http://www. spatialecology.com/htools

BirdLife International, 2013, Species factsheet: Gyps coprotheres, viewed 01 July 2013, from http://www.birdlife.org

BirdLife International, 2014a, Important Bird Areas SA088 Collywobbles Vulture Colony, viewed 23 June 2014, from http://www.birdlife.org.za/conservation/iba/ iba-directory/184-collywobbles

BirdLife International, 2014b, Important Bird Areas SA126 Pondoland Cape Vulture Colonies, viewed 23 June 2014, from http://www.birdlife.org.za/conservation/ policy-and-advocacy/item/381-sa126-pondoland-cape-vulture-colony

BirdLife South Africa, 2013, Important Birding Areas (IBA) Shapefile January 2013 viewed 15 December 2014, from http://bgis.sanbi.org/IBA/project.asp

Blundell, G.M., Maier, J.A.K. \& Debevec, E.M., 2001, 'Linear home ranges: effects of smoothing, sample size, and autocorrelation on kernel estimates', Ecological Monographs 71(3), 469-489. http://dx.doi.org/10.1890/0012 9615(2001)071[0469:LHREOS]2.0.CO;2

Boshoff, A., Barkhuysen, A., Brown, G. \& Michael, M., 2009, 'Evidence of partial migratory behaviour by the Cape Griffon Gyps coprotheres', Ostrich 80(3), 129133. http://dx.doi.org/10.2989/OSTRICH.2009.80.3.1.964

Boshoff, A. \& Minnie, J., 2011, 'On the role of the shape and size of foraging area, and colony size, in selecting critical areas for Cape Griffon Gyps coprotheres conservation action', Vulture News 61(1), 4-15.

Boshoff, A.F., Minnie, J.C., Tambling, C.J. \& Michael, M.D., 2011, 'The impact of power line-related mortality on the Cape Vulture Gyps coprotheres in a part of its range, with an emphasis on electrocution', Bird Conservation International 21(3), 311327. http://dx.doi.org/10.1017/S095927091100013X

Boshoff, A., Piper, S. \& Michael, M., 2009, 'On the distribution and breeding status of the Cape Griffon Gyps coprotheres in the Eastern Cape province, South Africa', Ostrich 80(2), 85-92. http://dx.doi.org/10.2989/OSTRICH.2009.80.2.4.831

Boshoff, A.F., Robertson, A.S. \& Norton, P.M., 1984, 'A radio-tracking study of an adult Cape griffon vulture Gyps coprotheres in the south-western Cape Province', South African Journal of Wildlife Research 14, 73-78.

Boshoff, A.F. \& Vernon, C.J., 1980, 'The past and present distribution and status of the Cape Vulture in the Cape Province', Ostrich 51, 230-250. http://dx.doi.org/10.10 80/00306525.1980.9633570

Botha, A., Allan, D., Krueger, S., Neethling, M., Neser, W., Pfeiffer, M. et al., 2012, Cape Vulture Task Force Report 2012: Wolter, K., Endangered Wildlife Trust, viewed n.d., from http://www.vulpro.com/publications/CVTF_Report_2012_final.pdf
Brown, C.J. \& Piper, S.E., 1988, 'Status of Cape Vultures in the Natal Drakensberg and their cliff site selection', Ostrich 59(3), 126-136. http://dx.doi.org/10.1080/0030 6525.1988.9633714

Burt, W.H., 1943, 'Territoriality and home range concepts as applied to mammals', Journal of Mammalogy 24(3), 346-352. http://dx.doi.org/10.2307/1374834

Byers, C.R., Steinhorst, R.K. \& Krausman, P.R., 1984, 'Clarification of a technique for analysis of utilization-availability data', The Journal of Wildlife Management 48(3), 1050-1053. http://dx.doi.org/10.2307/3801467

Diekmann, M., Scott, A., Scott, M. \& Diekmann, J., 2004, 'Capture and fitting of satellite- and radio-telemetry equipment onto Cape Griffon Vulture Gyps coprotheres, African White-backed Vulture Gyps africanus and Lappet-faced Vulture Torgos tracheliotus in the Waterberg area, Namibia in 2004', Vulture News 51(1), 34-45.

Dupont, H., Mihoub, J.B., Bobbé, S. \& Sarrazin, F., 2012, 'Modelling carcass disposal practices: implications for the management of an ecological service provided by vultures', Journal of Applied Ecology 49(2), 404-411. http://dx.doi.org/10.1111/ j.1365-2664.2012.02111.x

Endangered Wildlife Trust (EWT) and Ezemvelo KwaZulu-Natal (KZN) Wildlife unpublished data, Vulture feeding sites.

Fisher, E.C., Albert, R., Botha, G., Cawthra, H.C., Esteban, I., Harris, J. et al., 2013 , 'Archaeological Reconnaissance for Middle Stone Age Sites Along the Pondoland Coast, South Africa', PaleoAnthropology 1(1), 104-137.

Haas, D. \& Mundy, P., 2013, 'Vultures revered in time and place', Vulture News 63(1), 4-14.

International Union for Conservation of Nature and Natural Resources (IUCN) and United Nations Environment Programme's World Conservation Monitoring Centre (UNEP-WCMC), 2014, The World Database on Protected Areas (WDPA) Cambridge, UK: UNEP-WCMC, viewed 11 November 2014, from http://www. protectedplanet.net

Katzner, T.E., Brandes, D., Miller, T., Lanzone, M., Maisonneuve, C., Tremblay, J.A. et al., 2012, 'Topography drives migratory flight altitude of golden eagles: implications for on-shore wind energy development', Journal of Applied Ecology 49(5), 1178for on-shore wind energy development', Journal of Applied
1186. http://dx.doi.org/10.1111/j.1365-2664.2012.02185.x

Kendall, C.J., Virani, M.Z., Hopcraft, J.G.C., Bildstein, K.L. \& Rubenstein, D.I., 2014, 'African Vultures Don't Follow Migratory Herds: Scavenger Habitat Use Is Not Mediated by Prey Abundance', PLOS ONE 9(1), e83470. http://dx.doi.org/10.1371/ journal.pone.0083470

Kepe, T., 1997, 'Communities, Entitlements and Nature Reserves: The Case of the Wild Coast, South Africa', IDS Bulletin 28(4), 47-58. http://dx.doi. org/10.1111/j.1759-5436.1997.mp28004006.x

Lawes, M.J., Griffiths, M.E. \& Boudreau, S., 2007, 'Colonial logging and recent subsistence harvesting affect the composition and physiognomy of a podocarp dominated Afrotemperate forest', Forest Ecology and Managment 247(1-3), 4860. http://dx.doi.org/10.1016/j.foreco.2007.04.012

Mander, M., Diedericks, N., Ntuli, L., Mavundla, K., Williams, V. \& McKean, S., 2007 'Survey of the Trade in Vultures for the Traditional Health Industry in South Africa', FutureWorks, Everton, viewed n.d., from http://146.141.46.24/Craig/Raptors/ Mander\%20et\%20al\%202007\%20-\%20Vulture\%20trade\%20in\%20South\%20 Africa\%20-\%20Report.pdf

McKee, J.K., Sciulli, P.W., Fooce, C.D. \& Waite, T.A., 2004, 'Forecasting global biodiversity threats associated with human population growth', Biological Conservation 115(1), 161-164. http://dx.doi.org/10.1016/S0006-3207(03)00099-5

Moleón, M., Sánchez-Zapata, J.A., Margalida, A., Carrete, M., Owen-Smith, N. \& Donázar, J.A., 2014, 'Humans and Scavengers: The Evolution of Interactions and Ecosystem Services', BioScience 64(5), 1-10. http://dx.doi.org/10.1093/biosci/biu034

Monadjem, A. \& Garcelon, D.K., 2005, 'Nesting distribution of vultures in relation to land use in Swaziland', Biodiversity \& Conservation 14(9), 2079-2093. http:// dx.doi.org/10.1007/s10531-004-4358-9

Monsarrat, S., Benhamou, S., Sarrazin, F., Bessa-Gomes, C., Bouten, W. \& Duriez, O., 2013, 'How Predictability of Feeding Patches Affects Home Range and Foraging Habitat Selection in Avian Social Scavengers?', PLOS ONE 8(1), e53077. http:// dx.doi.org/10.1371/journal.pone.0053077

Mucina, L., Adams, J.B., Knevel, I.C., Rutherford, M.C., Bolton, J.J., Van der Merwe, J.H. et al., 2006. 'The vegetation of South Africa, Lesotho and Swaziland', in Mucina, L. $\&$ Rutherford, M.C. (eds.), Strelitzia, 19th ed., pp. 45, 510-511, 579, South African \& Rutherford, M.C. (eds.), Strelitzia, 19thal Biodiversity Institute, Pretoria.
Nation

Mundy, P., Butchart, D., Ledger, J. \& Piper, S., 1992, The vultures of Africa, Acorn Books, Randburg, Pretoria.

Mundy, P.J., 1982, The comparative biology of Southern African vultures, Vulture Study Group, Johannesburg.

Murn, C. \& Anderson, M.D., 2008, 'Activity patterns of African White-backed Vultures Gyps africanus in relation to different land-use practices and food availability', Ostrich 79(2), 191-198. http://dx.doi.org/10.2989/OSTRICH.2008.79.2.9.583

Ogada, D.L., Keesing, F. \& Virani, M.Z., 2012a, 'Dropping dead: causes and consequences of vulture population declines worldwide', Annals of the New York Academy of Sciences 1249(1), 57-71. http://dx.doi.org/10.1111/j.17496632.2011.06293.x

Ogada, D.L., Torchin, M.E., Kinnaird, M.F. \& Ezenwa, V.O., 2012b, 'Effects of Vulture Declines on Facultative Scavengers and Potential Implications for Mammalian Disease Transmission', Conservation Biology 26(3), 1-8. http://dx.doi. org/10.1111/j.1523-1739.2012.01827.x

Phipps, W.L., Willis, S.G., Wolter, K. \& Naidoo, V., 2013a, 'Foraging Ranges of Immature African White-Backed Vultures (Gyps africanus) and Their Use of Protected Areas in Southern Africa', PLOS ONE 8(1), e52813. http://dx.doi.org/10.1371/journal. pone.0052813 
Phipps, W.L., Wolter, K., Michael, M.D., MacTavish, L.M. \& Yarnell, R.W., 2013b, 'Do Power Lines and Protected Areas Present a Catch-22 Situation for Cape Vultures (Gyps coprotheres)?', PLoS ONE 8(10), e76794. http://dx.doi.org/10.1371/journal. pone.0076794

Piper, S.E., 1994, Mathematical demography of the Cape Vulture, PhD thesis, University of Cape Town, Cape Town.

Piper, S.E., 2005, 'Cape vulture', in Hockey, P.A.R., Dean, W.R.J. \& Ryan, P.G. (eds.), Roberts Birds of Southern Africa, 7th edn., pp. 489-491, John Voelcker Bird Book Fund, Cape Town.

Piper, S.E., Boshoff, A.F. \& Scott, H.A., 1999, 'Modelling survival rates in the Cape Griffon Gyps coprotheres, with emphasis on the effects of supplementary feeding', Bird Study 46, 230-238. http://dx.doi.org/10.1080/00063659909477249

Piper, S.E. \& Ruddle, P., 1986, 'An initial evaluation of the Cape Vulture colonies at Mkambati, Transkei', Vulture News 15(1), 7-12.

Powell, R.A., 2000, 'Animal home ranges and territories and home range estimators', in Boitani, L. \& Fuller, T.K. (eds.), Research Techniques in Animal Ecology: Controversies and Consequences, 2nd edn., pp. 79-80, Columbia University Press, New York.

Prakash, V., Pain, D.J., Cunningham, A.A., Donald, P.F., Prakash, N., Verma, A. et al., 2003, 'Catastrophic collapse of Indian white-backed Gyps bengalensis and Longbilled Gyps indicus vulture populations', Biological Conservation 109(3), 381-390. http://dx.doi.org/10.1016/S0006-3207(02)00164-7

Retief, E.F., Diamond, M., Anderson, M.D., Smit, H.A., Jenkins, A., Brooks, M. et al., 2013 Avian Wind Farm Sensitivity Map for South Africa: Criteria and Procedures Used.

Robertson, A.S. \& Boshoff, A.F., 1986, 'The feeding ecology of Cape vultures Gyps coprotheres in a stock-farming area', Biological Conservation 35(1), 63-86. http:// dx.doi.org/10.1016/0006-3207(86)90027-3

Rodgers, A.R., Carr, A.P., Beyer, H.L., Smith, L. \& Kie, J.G., 2007, Home Range Tools (HRT) for ArcGIS: Version 1.1, Ontario Ministry of Natural Resources, Centre for Northern Forestry Ecosystem Research, Thunder Bay, Ontario, Canada.

Ruxton, G.D. \& Houston, D.C., 2002, 'Modelling the energy budget of a colonial bird of prey, the Ruppell's griffon vulture, and consequences for its breeding ecology', African Journal of Ecology 40(3), 260-266. http://dx.doi.org/10.1046/j.1365 2028.2002.00368.x
South African National Botanical Institute (SANBI), 2000, National Land Cover Database, Pretoria, South Africa.

Shackleton, C.M., Granger, J.E., McKenzie, B. \& Mentis, M.T., 1991, 'Multivariateanalysis of coastal grasslands at Mkambati Game Reserve, north-eastern Pondoland, Transkei', Bothalia 21(1), 91-107.

Shackleton, R., Shackleton, C., Shackleton, S. \& Gambiza, J., 2013, 'Deagrarianisation and Forest Revegetation in a Biodiversity Hotspot on the Wild Coast, South Africa', PLOS ONE 8(10), 1-12. http://dx.doi.org/10.1371/journal.pone. 0076939

Sheehan, D.K. \& Sanderson, F.J., 2012, 'Seeing the bigger picture: How anthropogenic landscape modification in Africa affects declining migratory birds and the need for trans-continental research and conservation', Ibis 154(4), 659-662. http://dx.doi. org/10.1111/j.1474-919X.2012.01275.x

Skead, C.J., 1987, 'The eastern half of the Cape Province, including the Ciskei, Transke and East Griqualand', in Skead, C.J. (eds.), Historical mammal incidence in the Cape Province, pp. 80-82, Provincial Administration of the Cape of Good Hope, Department of Nature Conservation, Cape Town.

Spiegel, O., Harel, R., Getz, W. \& Nathan, R., 2013, 'Mixed strategies of griffon vultures' (Gyps fulvus) response to food deprivation lead to a humpshaped movement pattern', Movement Ecology 1(5), 1-12. http://dx.doi. org/10.1186/2051-3933-1-5

Statistics South Africa, 2011, Population per municipality, viewed 05 November 2012, from http://beta2.statssa.gov.za/

StatSoft, 2006, STATISTICA (data analysis software system): Version 7.1, http://www. statsoft.com

Swinhart, R. \& Slade, N., 1985, 'Influence of Sampling Interval on Estimates of HomeRange Size', The Journal of Wildlife Management 49(4), 1019-1025. http://dx.doi. org/10.2307/3801388

Vernon, C., 1998, 'The Cape Vulture at Collywobbles [sic.]: 1977-1997', Ostrich 70(3-1), 200-202.

Vetter, S. \& Bond, W.J., 2012, 'Changing predictors of spatial and temporal variability in stocking rates in a severely degraded communal rangeland', Land Degradation \& Development 23(2), 190-199. http://dx.doi.org/10.1002/ldr.1076 


\section{Appendix 1}

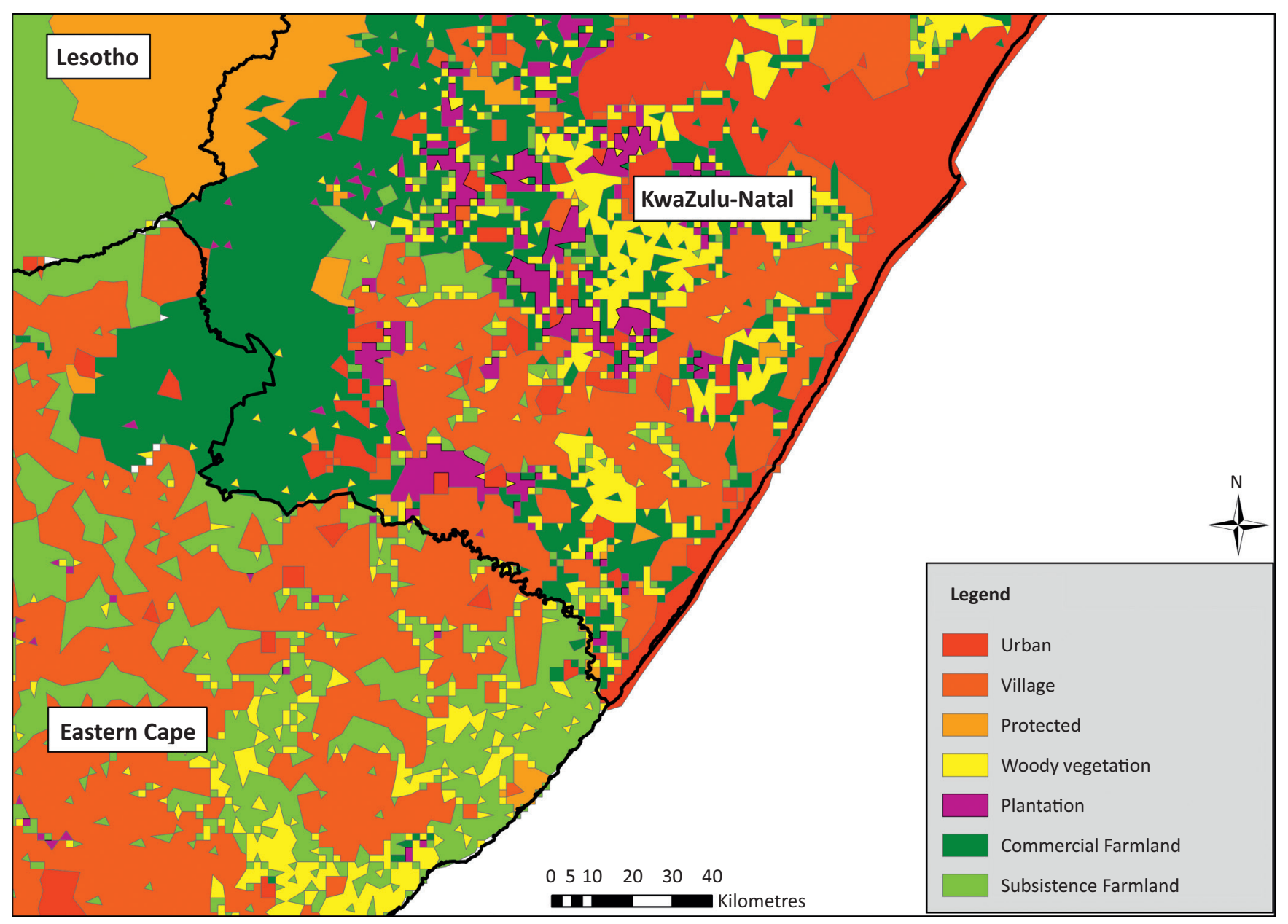

FIGURE A1: Land use map used for habitat analysis detailing the political boundaries of the former Transkei and Lesotho.

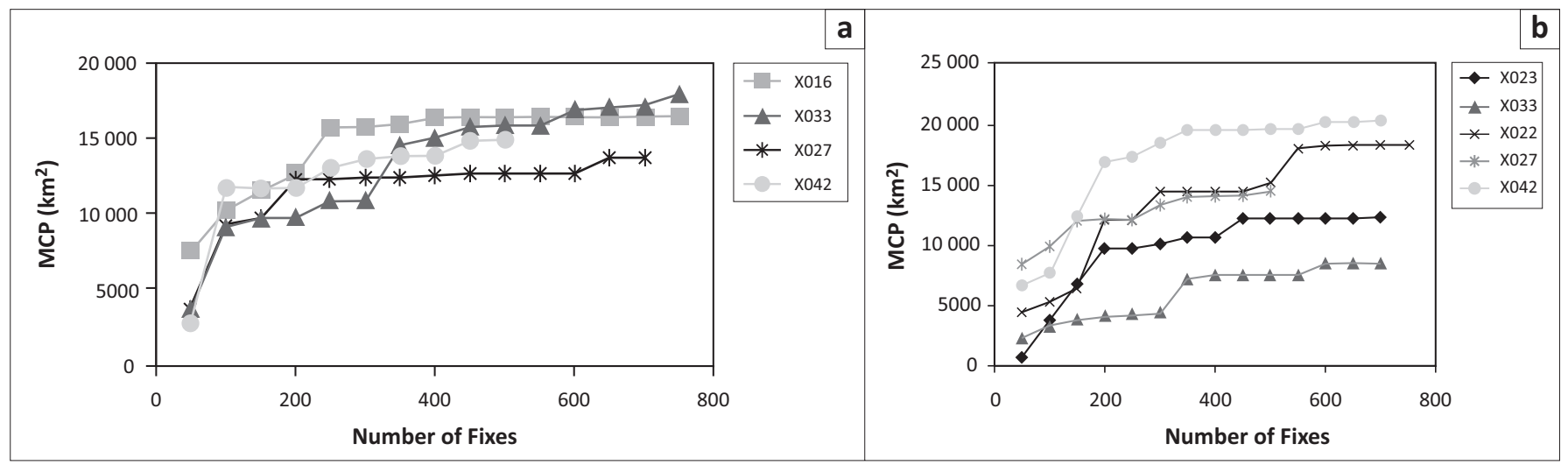

MCP, minimum convex polygons.

FIGURE A2: Incremental area analysis of minimum convex polygons of adult Cape Vultures (Gyps coprotheres) in relation to number of global positioning system location fixes for (a) the non-breeding season and (b) the breeding season, indicating that foraging range asymptotes were reached during each season. 
TABLE A1: Land use map reclassified categories. Original land use categories were based on the 2000 South African National Land Cover Database (South African National Botanical Institute 2000).

\begin{tabular}{|c|c|}
\hline Original Land Use Category & Reclassified Land Use Category \\
\hline Forest (indigenous) & Woody vegetation \\
\hline Woodland & Woody vegetation \\
\hline $\begin{array}{l}\text { Thicket, bushland, bush clumps, high } \\
\text { fynbos }\end{array}$ & Woody vegetation \\
\hline Shrubland and low fynbos & Commercial or subsistence farmland \\
\hline Natural grassland & Commercial or subsistence farmland \\
\hline Planted grassland & Commercial or subsistence farmland \\
\hline Forest Plantations (Eucalyptus spp.) & Plantation \\
\hline Forest Plantations (Pine spp.) & Plantation \\
\hline Forest Plantations (Acacia spp.) & Plantation \\
\hline Forest Plantations (other/mixed spp.) & Plantation \\
\hline Forest plantations (clearfelled) & Plantation \\
\hline Water bodies & Commercial or subsistence farmland \\
\hline Wetlands & Commercial or subsistence farmland \\
\hline Bare rock and soil (natural) & Commercial or subsistence farmland \\
\hline $\begin{array}{l}\text { Bare rock and soil (erosion: dongas/ } \\
\text { gullies) }\end{array}$ & Commercial or subsistence farmland \\
\hline Bare rock and soil (erosion: sheet) & Commercial or subsistence farmland \\
\hline Degraded forest and woodland & Woody vegetation \\
\hline Degraded thicket, bushland & Woody vegetation \\
\hline Degraded shrubland and low fynbos & Commercial or subsistence farmland \\
\hline $\begin{array}{l}\text { Degraded unimproved (natural) } \\
\text { grassland }\end{array}$ & Commercial or subsistence farmland \\
\hline $\begin{array}{l}\text { Cultivated, permanent, commercial, } \\
\text { irrigated }\end{array}$ & Commercial farmland \\
\hline $\begin{array}{l}\text { Cultivated, permanent, commercial, } \\
\text { dryland }\end{array}$ & Commercial farmland \\
\hline $\begin{array}{l}\text { Cultivated, permanent, commercial, } \\
\text { sugarcane }\end{array}$ & Commercial farmland \\
\hline
\end{tabular}

TABLE A1 continues $\rightarrow$
TABLE A1 (Continues...): Land use map reclassified categories. Original land use categories were based on the 2000 South African National Land Cover Database (South African National Botanical Institute 2000).

\begin{tabular}{|c|c|}
\hline Original Land Use Category & Reclassified Land Use Category \\
\hline $\begin{array}{l}\text { Cultivated, temporary, commercial, } \\
\text { irrigated }\end{array}$ & Commercial farmland \\
\hline $\begin{array}{l}\text { Cultivated, temporary, commercial, } \\
\text { dryland }\end{array}$ & Commercial farmland \\
\hline $\begin{array}{l}\text { Cultivated, temporary, subsistence, } \\
\text { dryland }\end{array}$ & Subsistence farmland \\
\hline $\begin{array}{l}\text { Cultivated, temporary, subsistence, } \\
\text { irrigated }\end{array}$ & Subsistence farmland \\
\hline Urban/built-up & Urban \\
\hline Urban/built-up (rural cluster) & Village \\
\hline $\begin{array}{l}\text { Urban/built-up (residential, formal } \\
\text { suburbs) }\end{array}$ & Urban \\
\hline Urban/built-up (residential, flatland) & Urban \\
\hline Urban/built-up (residential, mixed) & Urban \\
\hline Urban/built-up (residential, hostels) & Urban \\
\hline $\begin{array}{l}\text { Urban/built-up (residential, formal } \\
\text { township) }\end{array}$ & Village \\
\hline $\begin{array}{l}\text { Urban/built-up (residential, informal } \\
\text { township) }\end{array}$ & Urban \\
\hline Urban/built-up (informal squatter camp) & Urban \\
\hline Urban/built-up (smallholdings) & Urban \\
\hline Urban/built-up (commercial, mercantile) & Urban \\
\hline $\begin{array}{l}\text { Urban/built-up (commercial, education, } \\
\text { health, IT) }\end{array}$ & Urban \\
\hline $\begin{array}{l}\text { Urban/built-up (industrial/transport: } \\
\text { heavy, light) }\end{array}$ & Urban \\
\hline Mines and quarries (subsurface mining) & Commercial or subsistence farmland \\
\hline
\end{tabular}

